\title{
Grasping the Ineffable: Interdisciplinary Perspectives on Mood
}

\author{
Birgit Breidenbach* \\ Department of English and Comparative Literary Studies, University of Warwick \\ *Correspondence: B.Breidenbach@warwick.ac.uk
}

\begin{abstract}
The question of mood deeply affects a variety of disciplines such as psychology, sociology, philosophy and the arts. As an emerging new field in both disciplinary and interdisciplinary research, mood became the focal point of the conference 'Mood: Aesthetic, Psychological and Philosophical Perspectives', held at Warwick in 2016, which set out to explore the nature of mood and develop ways of conceptualising and researching it through an interdisciplinary lens. A series of keynote lectures, creative performances and parallel sessions led to a varied and productive exchange of disciplinary perspectives that helped to outline the main questions and concerns the emerging research topic of mood constitutes, uncovering the pivotal role it plays in aesthetic, social and political contexts.
\end{abstract}

Keywords: mood, affect studies, interdisciplinary research, aesthetics, philosophy, psychology

Funding: See page 314

Peer review: This article has been subject to a double blind peer review process

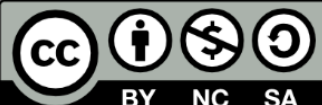

C Copyright: The Authors. This article is issued under the terms of the Creative Commons Attribution NonCommercial Share Alike License, which permits use and redistribution of the work provided that the original author and source are credited, the work is not used for commercial purposes and that any derivative works are made available under the same license terms.
To many, 2016 was a particularly tumultuous year in world history: from the divisive Brexit vote to the controversial outcome of the American presidential election, from the ongoing strains of the European refugee crisis and numerous atrocious terrorist attacks all around the world to the perceived mass dying of major artists and public personalities like David Bowie and Muhammad Ali, the public mood of the past year may have been at an all-time low. The impactful social and political moods of the recent past are complimented by a present-day emphasis on private moods and ways of managing them: on the popular music streaming platform Spotify, songs are now not only ordered by genres, but also by mood, according to their website in order to match listeners' moods and to 'soundtrack [their] life with a playlist to fit any moment'. Likewise, the new 'Elf Emmit' device is advertised as a 'digital metronome' that means to physiologically induce different moods: 'sleep', 'antistress', 'concentrate', 'meditate' and 'deep learning', while the video chat application Skype allows users to add a 'Mood Message' to their profile 
to communicate their states of mind to their social contacts, as do other social media platforms in similar ways. 'Mood lights', 'mood rings' and other products are meant to adjust and express our daily moods, while pharmaceutical 'mood stabilisers' like anti-depressants are supposed to manage the wide-spread psychiatric mood disorders of our day.

Our age's obsession with moods, private and public, may betray a sense of crisis and fracture in many areas of modern life, but it may also showcase a growing awareness of the conditions of everyday life and the ways in which moods enable and affect our every experience. In his defining work Being and Time (1927), Martin Heidegger postulates that we are never not in a mood or 'attunement' (in German, Stimmung, cf. Heidegger, 1962: 172f.). The inconspicuousness of our daily moods, many of which can be barely noticeable, often only becomes apparent in a state of Verstimmung, of being 'out of tune' with the world or being bad-tempered. 'One mood can be replaced by another', contemporary philosopher Lars Svendsen finds, 'but it is impossible to leave attunement altogether' (Svendsen, 2005: 114). The omnipresence of mood in our daily lives, indeed the way it enables them in the first place, and the manner in which it thereby informs all academic thought and activity, call for a study of its nature and impact in a number of areas, including, though not limited to, philosophy, psychology, sociology and the arts. As such, mood is inherently interdisciplinary: The works of Heidegger, Sartre, Kierkegaard and Kant have established it as a central concern of modern philosophy. Psychology and psychiatry illuminate the role of mood in cognition, behaviour and psychosomatic illnesses. Sociology investigates mood in social interactions, groups and communities, while political science studies its impact on politics on a national and international stage. Finally, the arts examine the emergence and transmission of aesthetic moods in different media, including literature, film, theatre and music. Recent work on this phenomenon has considerably advanced the study of this theoretically challenging concept and has put it on the map of current research in a variety of disciplines: in literary studies Hans Ulrich Gumbrecht's influential book Atmosphere, Stimmung, Mood: On a Hidden Potential of Literature (2012), in political science John L. Casti's Mood Matters: From Rising Skirt Lengths to the Collapse of World Powers (2010), in philosophy Philosophy's Moods: The Affective Grounds of Thinking (2011), edited by Hagi Kenaan and Ilit Ferber, and in psychology and sociology Jaap van Ginneken's Mood Contagion: Mass Psychology and Collective Behaviour Sociology in the Internet Age (2013).

All of the aforementioned disciplines work with a different concept of mood, and all of them have equal claim to it. In a newly emerging field of such vast potential, interdisciplinary work using that synergy only suggests itself, and might even be necessary to grasp a concept as 
multifaceted and complex as mood is. The conference Mood: Aesthetic, Psychological and Philosophical Perspectives, which took place at the University of Warwick in May 2016, set out to establish a cutting-edge platform for exploring mood in an interdisciplinary way, being the first international event that brought together a wide array of disciplines to discuss this subject matter from a diverse and differentiated perspective. Sponsored by the Humanities Research Centre, the Department of English and Comparative Literary Studies and the Centre for Research in Philosophy, Literature and the Arts at Warwick, the Mood conference featured academic keynote lectures by Hans Ulrich Gumbrecht (Albert Guérard Professor in Comparative Literature, Stanford University), Giovanna Colombetti (Associate Professor in Sociology, Philosophy and Anthropology, University of Exeter) and Hagi Kenaan (Professor of Philosophy, Tel Aviv University) as well as a keynote reading by accomplished nonfiction author Mary Cappello (Professor of English and Creative Writing, University of Rhode Island). In addition to this, another 39 speakers presented their research in twelve panels spread across the two-day event. Including speakers from six continents, based in over a dozen academic disciplines and forms of creative practice, the programme represented the diverse, multi-faceted nature of worldwide research on mood. The initial guiding questions for the event could be summarised as the following: how do concepts of mood and ways of researching it differ among disciplines, and (how) can they be brought together? Where do these disciplines collide, and what does this tell us about the nature of mood? Is mood primarily a phenomenon of the subject, or is it inherently social? What are the politics of mood, and what is its place in current scholarship across the sciences and the humanities? The discussions that took place over the course of the event demonstrated that the visceral and intersubjective nature of mood itself helped bridging disciplinary differences and boundaries in discussing this phenomenon as the moods the conference itself produced enveloped delegates in a shared experience encountered with a, naturally, heightened sensitivity.

One of the central recurrent questions addressed throughout the conference was that of the place of mood. In her keynote lecture on the 'extended-mind-thesis' and the concept of incorporation, Giovanna Colombetti argued that, when a mood emerges from the moment-bymoment reciprocal interactivity of a person with an object (such as a musical instrument) and the person experiences the object as part of herself, we can regard the mood as 'extended' - in the sense that it is physically constituted not just by the biological organism, but by the hybrid system of 'person-plus-object'. In a joint panel discussing the influence of mood on politics and economics, Dennis Elam (Texas A\&M 
University-San Antonio), Alan Hall and Matt Lampert (both from the Socionomics Institute in Gainesville, GA) presented the Socionomic perspective on mood, according to which moods appear in social waves that shape socio-politic reality. From this point of view, mood is an inherently intersubjective social phenomenon. Douglas Bachorik's (University of Durham) paper on the role of mood in religious communities, more specifically in choir-singing, brought together both perspectives in examining forms of embodied affect in the social group of a congregation, thus constituting a 'corporate body'. The workings of mood in art took on a significant role during the event, with Mary Cappello's highly visceral multisensory reading from her new book Life Breaks In: A Mood Almanack (2016) foregrounding its role both in the artistic process and in aesthetic experience, further corroborated by artist Katja K. Hock's (Nottingham Trent University) installation 'Buchenwald', which was showcased at the conference, and paper on the same theme. Indeed, spaces of mood were explored by a number of contributors, including Jon Arcaraz Puntonet's (University of Navarra) presentation on architecture and rhythm, relating to a design by Spanish architect Fernando Higueras, Joshua Burraway's (UCL) discussion of boredom and urban homelessness in London and Christopher Donaldson's (University of Birmingham) examination of mood and literary representations of the Morecambe Bay Sands.

At the same time, the question of mood's temporality arose in Hagi Kenaan's keynote lecture on 'changing moods' (in the double sense of the expression), in which he proposed that 'there is no such thing as a mood' as moods only exist in the plural sense. Kenaan further argued that every mood already contains the possibility of a future mood and that they are therefore by definition never singular and closed off. In close connection to this idea, Hans Ulrich Gumbrecht's final keynote lecture historicised the concept of mood, tracing it throughout the history of literary criticism and raising the question of why it has, until recently, been a blind spot of criticism. Relating literary moods to the concepts of aesthetic presence and immersion, Gumbrecht's talk built on his recent book on Stimmung, in which he defines moods as a 'presencerelated part of existence' (Gumbrecht, 2012: 7). In vein with such perspectives on the temporality of mood, a number of contributions explored historical and aesthetic instances of mood, including Madeleine Scherer's (Warwick) and Ryan Pepin's (University of Cambridge) papers on moods in the classical literature of Homer and Virgil, respectively, Maria Rita Drumond Viana's (Universidade Federal de Santa Catarina) presentation on Yeats' changing concept of mood in art and Daniel Tiemeyer's (University of Vienna) paper on moods in the music of Viennese modernism. 
Another absolutely central concern regarding the nature of mood crystallised out of a number of contributions that discussed the question of agency and intentionality with regards to mood and which, in consequence, posed the question of its politics and ethics. Jonathan Mitchell (Warwick) proposed that despite common definitions, moods can have intentionality and intentional objects, an idea also discussed in the talks by Colombetti and Emmanuel Ordóñez Angulo (UCL). From the notion of intentionality results the question of how moods affect agency, and by extension, responsibility. In line with this, Alireza

Fakhrkonandeh's (Warwick) talk on affect and ethics in the theatre of Howard Barker explored the notions of self and other negotiated through inter-affective relationships in the plays. Likewise, the question of ethics and the 'other' reappeared in a panel on depression, which featured Jake Jackson (Temple University) discussing depressive responsibility and Constantin Mehmel (Warwick) suggesting that depression is a mood that radically 'others' those affected by it. The political dimension of mood, which was opened up both by the Socionomic discussion of social moods and continued in the debates on mood and ethics, also encompassed thoughts on mood and gender, with talks by Mohammad Shahidul Islam Chowdhury (East Delta University) and Mary Harrod (Warwick), as well as postcolonial perspectives explored in Harjinder Singh Majhail's (University of Derby) talk on religious moods in relation to Sikh identity and Oliver Paynel's analysis of mood in Zadie Smith's postcolonial novel White Teeth (2000). The postcolonial point of view hinted towards another crucial aspect in studying mood: its (inter-)cultural dimension. Both Vladimír Gärtner's (Masaryk University) study of the reception of Turkish art music by Western listeners and Hyun Höchsmann's (East China Normal University) discussion of Heidegger's notion of Stimmung in the context of Daoism offered cross-cultural perspectives on mood, which raised the question of how culturally specific moods are and whether they can be 'translated' into other cultures. Manifold other issues revolving around the concept of mood were raised in the course of the conference, underlining the complexity and vastness in scope this phenomenon demonstrates.

In conclusion, by producing its own productive, collegial and sometimes discordant moods, the two-day event provided a rich and impressive display of the state of the art in research on mood in different disciplines and cultural context. While uncovering the breadth of mood-related issues in a number of disciplines, the conference also provided a roadmap for future research and allowed us to identify the main questions and concerns for this emerging new interdisciplinary field: the spatiality and temporality of mood, the questions of its intentionality, responsibility and ethics, as well as its cultural specificity and cross- 
cultural capacity. We are currently planning on furthering the productive potential of this plurality of disciplinary viewpoints, as well as the valuable and indicative tensions that arose from the discussions over the two days, in a collection of essays based on the papers given at this conference. The aim of this publication is to give a comprehensive overview of the state of the art of research on mood in various disciplines, to outline theoretical and practical ways of approaching it through an interdisciplinary lens, and finally, to provide case studies of the role mood plays in various aesthetic, social and political contexts. Through further theoretical and applied research on this pivotal aspect of human life and social interaction, we will gain more insight into the affective dimension that informs both our private and public lives in so many ways.

For more information and to view the programme, visit the conference website:

http://www2.warwick.ac.uk/fac/arts/english/research/conferences/moo d2016

\section{Acknowledgments}

The organisers would like to thank the HRC, Department of English and Comparative Literary Studies and CRPLA at Warwick for their generous financial support of this event. Furthermore, the clerical help provided by Sue Rae and Heather Pilbin during the preparations for this conference proved to be invaluable. Finally, we would, once again, like to thank all speakers, helpers and colleagues who chaired panel sessions and lectures for attending and bringing their wonderful research, varied perspectives and kind and positive moods to this event. 


\section{References}

Cappello, Mary (2016), Life Breaks In: A Mood Almanack, Chicago and London: University of Chicago Press

Casti, J.L. (2010), Mood Matters: From Rising Skirt Lengths to the Collapse of World Powers, New York: Copernicus Books

Colombetti, G. (2014), The Feeling Body: Affective Science Meets the Enactive Mind, Cambridge, MA, and London: The MIT Press

Gumbrecht, H. U. (2012), Atmosphere, Stimmung, Mood: On a Hidden Potential of Literature [2011], Trans. E. Butler, Stanford, CA: Stanford UP

Heidegger, M (1962), Being and Time, Trans. J. Macquarrie \& E. Robinson, New York et al.: Harper Collins

Kenaan, H. and I. Ferber (eds.) (2011), Philosophy's Moods: The Affective Grounds of Thinking (2011), Dordrecht et al.: Springer

Svendsen, L. (2005), A Philosophy of Boredom, Trans. J. Irons, London: Reaction Books

van Ginneken, J (2013), Mood Contagion: Mass Psychology and Collective Behaviour Sociology in the Internet Age, The Hague: Eleven International Publishing

\section{To cite this article:}

Breidenbach, B. (2017). Grasping the Ineffable: Interdisciplinary Perspectives on Mood. Exchanges: The Warwick Research Journal, 4(2), 309315. Retrieved from:

http://exchanges.warwick.ac.uk/index.php/exchanges/article/view/147 